УДК 349.22

DOI https://doi.org/10.32844/2618-1258.2019.5-1.17

ІСАКОВ М.Г., ПАРКУЛАБ В.Г.

\title{
ОСОБЛИВОСТІ ТРУДОВИХ ВІДНОСИН У СУЧАСНИХ УМОВАХ ІНФОРМАЦІЙНИХ ТЕХНОЛОГІЙ
}

Стаття присвячена з'ясуванню особливостей правового регулювання трудових відносин в умовах становлення інформаційно-комунікаційних технологій, визначення сфери реалізації працівниками права на конфіденційність у мережі Інтернет, оскільки перевищення меж втручання будь-якого суб'єкта в приватне життя створює можливості для зловживань ії суб'єктивними правами.

Захист трудових прав не належить до питань, що безпосередньо пов'язані 3 управлінням інтернет-ресурсами. Проте інтернет, проникаючи в усі сфери суспільного життя, суттєво впливає на реалізацію трудових прав і обов'язків. Це зумовило включення до переліку прав, що охороняються Хартією прав людини, і принципів для інтернету права на працю.

Важливу проблему з точки зору захисту прав людини становить забезпечення гарантій захисту персональних даних працівника з його профілів на сайтах соціальних мереж, які можуть вплинути на працевлаштування особи.

Сучасний рівень розвитку інформаційно-комунікаційних технологій дає змогу окремим категоріям співробітників виконувати свої професійні обов'язки без обов'язкової присутності на робочому місці, тобто віддалено. Для виконання багатьох трудових функцій не треба регулярно з'являтися на робочому місці в термін, встановлений правилами внутрішнього трудового розпорядку.

Сучасні зміни, що відбуваються в соціально-трудових правовідносинах, вимагають розробки нової структурно цілісної, узгодженої за цілями та методами правової стратегії врегулювання суспільних відносин в умовах цифрових технологій. Нині дедалі більше українців віддають перевагу дистанційній та надомній роботі, яка дає змогу гідно заробляти не лише фахівцям певних галузей, а й мало захищеним верствам населення: пенсіонерам, багатодітним жінкам, матерям-одиначкам. Однак, якщо суспільство вже цілком та повністю готове сприймати, втілювати в життя та отримувати реальні результати від такої співпраці, вітчизняне законодавство лише налаштовується на нові відносини. Пріоритетними напрямами законодавчого регулювання трудових відносин $є$ сучасні тенденції та практика поєднання інформаційних технологій і трудових відносин, інструменти IT-нагляду та контролю за дотриманням правил внутрішнього трудового розпорядку, умови забезпечення можливості віддаленої роботи тощо.

Ключові слова: правові відносини, інформаційні технології, дистаниійна прачя, фріланс-зайнятість, право на конфіденщійність праччівника.

The article is devoted to finding out the peculiarities of the legal regulation of labor relations in the conditions of the formation of information and communication technologies, to determine the sphere of realization of the right to privacy on the Internet, since the interference of any subject in private life creates opportunities for abuse of its subjective rights.

Protection of labor rights does not relate to issues directly related to the management of Internet resources. However, the Internet, having penetrated into all spheres of public life, has a significant impact on the exercise of labor rights and responsibilities. This led to the inclusion in the list of rights protected by the Charter of Human Rights and the principles of the Internet right to work.

(C) ІСАКОВ М.Г. - доктор юридичних наук, адвокат, президент (Юридична фірма «Глобус»)

(C) ПАРКУЛАБ В.Г. - кандидат юридичних наук, адвокат, керуючий партнер (Юридична фірма «Глобус») 
An important problem in terms of human rights protection is the provision of safeguards to protect the employee's personal information from their profiles on social networking sites that may affect the employment of the individual.

The current level of development of information and communication technologies allows certain categories of workers to fulfill their professional duties without the obligatory presence in the workplace, remotely. To perform many job functions, you do not need to regularly appear at the workplace within the timeframe specified by the internal workplace rules.

Modern changes occurring in social and labor relations require the development of a new structurally coherent, agreed on the goals and methods of a legal strategy for the regulation of social relations in the digital environment. Today, more and more Ukrainians are opting for remote and home-based work that allows them to earn decent income not only for professionals in certain industries, but also for the few protected sections of the population: pensioners, many women, single mothers. However, if the society is already fully and fully prepared to perceive, bring to life and receive real results from such cooperation, domestic legislation is only adjusting to new relations. Priority areas of legislative regulation of labor relations are current trends and practices of combining information technology and labor relations, tools for IT surveillance and control over compliance with the rules of internal labor regulations, conditions for ensuring remote work.

Key words: legal relations, information technologies, remote work, freelance employment, right to employee confidentiality.

Вступ. Для вдосконалення правового регулювання трудових відносин важливе значення має посилення взаємозв'язків і розширення співпраці працівників і роботодавців як на внутрішньому, так на зовнішньому рівнях управлінської діяльності (наприклад, трудових колективів та адміністрацій підприємств всередині одного відомства, в межах тієї чи іншої галузі економіки, міжвідомчих або міжгалузевих структур). Сучасні інформаційні технології, перш за все інтернет, забезпечують значні можливості для такої взаємодії. Зокрема, вони надають можливості для міжвідомчих консультацій і миттєвої передачі будь-яких обсягів інформації (текстових, аудіота візуальних повідомлень), стрімко поширюється так звана «взаємодія після натискання однієі кнопки» незалежно від часу і географічної відстані.

Постановка завдання. Метою статті є визначення основних трансформацій у системі трудових відносин, викликаних сучасними тенденціями поєднання інформаційних технологій і трудових відносин, новими інструментами ІТ-нагляду та контролю за дотриманням правил внутрішнього трудового розпорядку, новими можливостями віддаленої роботи. Важливим завданням юридичної науки є розуміння сучасних викликів, перед якими постає сфера реалізації трудових прав і обов'язків, для вибору напрямів якісної модифікації трудових правовідносин та розроблення адекватних механізмів іх регулювання.

Теоретико-прикладні аспекти інформаційного суспільства досліджені такими вченими: Ю. Бажал, В. Гасслер, В. Геєць, С. Дятлов, С. Іляшенко, В. Іноземцев, В. Кремень, Л. Мельник, В. Осецький, В. Семиноженко, В. Тарасевич, Л. Федулова, А. Чухно, та інші. Незважаючи на численність публікацій, варто зазначити недостатність робіт, які б розкривали сутність трансформацій трудових відносин в умовах інформаційних технологій.

Результати дослідження. Інформаційні технології розширили можливості комунікації як для роботодавців, так і для самих працівників. Наприклад, працівникам стає простіше звертатися до необхідних інформаційних ресурсів, не завжди доступних в самих установах. Своєю чергою, це дає змогу знизити адміністративне навантаження на співробітників HR-підрозділів, зменшивши кількість або повністю усунувши повторні звернення за однією і тією самою інформацією. Загалом інтеграція інформаційно-комунікаційних технологій в управлінні трудовими ресурсами може привести до заміни традиційних бюрократичних режимів управління (вертикальна схема) більш відкритим, гнучким цифровим управлінням.

Існує позитивний італійський досвід, коли Міністерство праці та соціальної політики Італії використовує централізовану систему, яка виконує процедуру ретельної автентифікації, що заснована на управлінні особистими обліковими даними, перш ніж надати користувачам доступ до іiі даних. Тобто доступ працівників і адміністрації до інтернету надається залежно від автентифікації користувача. Зміст усіх вебсайтів, до яких надається доступ автентифікованим користувачам, аналізується і перевіряється на наявність вірусів, а заражені файли блокуються. Крім того, 
усім працівникам надаються комп'ютери зі стандартним програмним забезпеченням, що надає стандартний профіль додатків до нього та запобігає встановленню або використанню потенційно небезпечного програмного забезпечення. Для поліпшення управління організацією людських ресурсів усі державні агенції з працевлаштування мають широкі можливості у використанні переваг передових технологічних досягнень для обробки величезних обсягів інформації, обміну та доступу до даних, а також передачі інформації працівникам [1].

Робітник має бути захищений нормами трудового права ще до працевлаштування. Неприпустимі випадки дискримінації за ознакою наявності в кандидатів на посаду доступу до соціальних мереж і специфічного змісту їхніх особистих сторінок. Як відомо, частина кандидатів на посаду мають онлайн-профіль у соціальних мережах, а частина - ні. 3 великою вірогідністю роботодавець винайме кандидата, який зареєстрований у соціальних мережах, тому що, по-перше, отримає більше інформації про нього, а по-друге, тому, що може припустити, що ці кандидати технічно більш розвинені, ніж ті, в кого немає профілю в соціальних мережах. Така ситуація свідчить про дискримінацію щодо кандидатів, які не мають онлайн-профілю.

Використання соціальних мереж є загальним інструментом HR-фахівців у процесі прийому на роботу нових співробітників, тому що соціальні мережі можуть надати значну інформацію про людину, в тому числі, іноді дуже особистого характеру.

Важливу проблему з точки зору захисту прав людини становить забезпечення гарантій захисту персональних даних працівника з його профілів на сайтах соціальних мереж, які можуть вплинути на працевлаштування особи. Винятком можуть бути лише ситуації, коли необхідність врахування подібної інформації про людину зумовлена специфікою роботи і це чітко передбачено корпоративними вимогами оцінки кандидатів.

Такий приклад ми бачимо в законодавстві Португалії, де серед норм про захист персональних даних є така: роботодавець не може вимагати надання інформації про особисте життя, за винятком випадків, коли така інформація є вкрай необхідною під час оцінки можливостей кандидата на посаду для виконання трудового договору.

Більшість сайтів застосовують політику конфіденційності з різними параметрами такої конфіденційності. І якщо на одних сайтах загальні параметри конфіденційності автоматично встановлюються для всіх користувачів, то на інших - вся інформація може бути доступна будь-кому, якщо користувач особисто не налаштує параметри конфіденційності. У такому разі недоторканність приватного життя кандидатів буде більш захищена, а роботодавець не зможе побачити їхні особисті дані. Роботодавець не може вимагати від працівника або кандидата на посаду інформацію про його профілі в соціальних мережах. Кандидат не зобов'язаний повідомляти майбутньому роботодавцеві свій пароль, додавати його в «друзі» або надавати будь-яку іншу інформацію, яка б дозволила отримати доступ до персональної інформації своїх співробітників або кандидатів на посаду.

Дискримінація співробітників за ознакою статі, віку, раси або етнічного походження, релігії, сексуальної орієнтації або сімейного стану заборонена на рівні Європейського Союзу. Проте кандидату на посаду дуже важко довести, що йому було відмовлено у прийомі на роботу саме на підставі інформації, добутої із соціальних мереж.

Цілі збирання інформації про персональні дані мають бути явними, тобто повністю і чітко вираженими, та законними. Це означає, що персональні дані працівників, у тому числі із соціальних мереж, можуть збиратися і розглядатися, якщо їх одержання відповідає зазначеним цілям. Дуже важливо, щоб мета була конкретно визначена, тому що тільки так може бути забезпечена відповідність персональних даних, які були оброблені, визначеним у законі цілям.

Мета обробки персональних даних має відповідати правовим і етичним нормам, насамперед, основоположним правам і свободам людини. Цей принцип є суттєвою перешкодою необгрунтованої обробки персональних даних, у тому числі в профілях користувачів соціальних мереж [2].

Що стосується роботи з використанням інтернету, то найбільш поширеним прикладом $є$ віддалена, або дистанційна, форма праці. Сучасний рівень розвитку інформаційно-комунікаційних технологій дає змогу окремим категоріям співробітників виконувати професійні обов'язки без обов'язкової присутності на робочому місці, тобто віддалено. Для виконання багатьох трудових функцій не треба регулярно з'являтися на робочому місці у термін, встановлений правилами внутрішнього трудового розпорядку.

Це призводить, своєю чергою, до формування іншого стилю управління персоналом, пошуку нових методів управління і контролю за результатами праці на відстані, зокрема, такий механізм управління виявляється особливо ефективним у малих трудових колективах. 
Під дистанційною працею розуміється виконання визначеної трудовим договором робочої функції поза місцем перебування роботодавця, його філії, представництва, іншого відокремленого структурного підрозділу (включаючи іншу місцевість), поза стаціонарним робочим місцем, територією або об'єктом, що прямо або опосередковано перебуває під контролем роботодавця, за умов використання інформаційно-телекомунікаційних мереж загального користування, включаючи інтернет, для виконання цієї трудової функції і для здійснення взаємодії між роботодавцем $\mathrm{i}$ працівником із питань, пов'язаних з її виконанням.

Визначальною ознакою дистанційної праці є використання інформаційно-телекомунікаційних мереж загального користування, в тому числі інтернету, для виконання трудової функції і взаємодії з роботодавцем. У законодавчих актах немає чіткої відповіді на питання, чи пов'язана дистанційна праця виключно з використанням інтернету, наприклад праця IT-фахівця, або ж дистанційним працівником вважається співробітник, який віддалено виконує будь-яку роботу та використовує інтернет тільки для здійснення комунікації з роботодавцем [3].

Дистанційних працівників треба відрізняти від надомників. На відміну від надомників, у дистанційних працівників немає певного робочого місця, свою роботу вони можуть виконувати не тільки в домашніх умовах, але і в будь-якому іншому місці, де $\epsilon$ доступ до інтернету. Так, згідно з Конвенцією МОП, особи зі статусом найманих працівників не вважаються надомниками лише через наявність одного факту - виконання ними час від часу роботи вдома, а не на своєму звичайному робочому місці [4].

Щоб уникнути плутанини, необхідно визначити відмінності між дистанційною зайнятістю та роботою так званих фрілансерів (від англ. Freelancer - вільний стрілець) - фахівців, які можуть одночасно виконувати замовлення для різних роботодавців (клієнтів). Дистанційна робота передбачає офіційне працевлаштування в компанії на вакансію працівника з відділеним режимом роботи, незалежно від місця його перебування. Пройти всі етапи влаштування на роботу, включаючи співбесіду з роботодавцем, дають змогу сучасні інформаційні технології, зокрема, інтернет дає змогу підписати всі потрібні документи за допомогою електронної пошти. Робота фрілансера, на відміну від віддаленої роботи, $є$ різновидом приватного бізнесу. Оплата такої праці залежить від рівня і досвіду роботи самого фрілансера. Відповідно, є відмінності і в його правовому статусі, і в правовому регулюванні такої діяльності, так само як і в реалізації трудових прав і обов'язків та їх захисті від порушень.

Варто зазначити також існування особливостей доступу до інтернет-ресурсів для деяких категорій працівників, що зумовлені специфікою місця їх роботи, зокрема, забезпечення доступу до інтернету для моряків далекого плавання. Відповідно до Конвенції МОП передбачено в розумних межах надавати доступ до телефонного зв'язку між судном і берегом, засобів електронної пошти та інтернету, за їх наявності, причому розмір оплати за користування цими послугами не має перевищувати розумних меж [5].

Інша специфічна ситуація, коли робота деяких співробітників проходить переважно в Мережі та $є$ безпосередньо їхнім робочим місцем. Такі категорії працівників мають право розраховувати на те, що роботодавець забезпечить їм постійний і безперешкодний доступ до інтернету. Працівники також можуть виконувати свою роботу, переміщаючись у мобільних офісах по регіонах. При цьому їхня професійна діяльність - зустрічі з потенційними партнерами, передача і контроль інформації, а також безліч інших організаційно-управлінських операцій - об' єктивно не вкладається в передбачені законодавством норми часу, а підпадає під режим ненормованого робочого дня [6].

Не доводиться сумніватися в тому, що працівники мають фундаментальне право на приватне життя. Також незаперечним $\epsilon$ те, що роботодавці цілком правомірно зацікавлені в збереженні комерційної таємниці і встановленні необхідного контролю за використанням робочого часу своїх співробітників. Однак вирішити цю колізію керівники компаній нерідко намагаються не завжди правовими способами.

Для збереження комерційної таємниці і контролю за робочим часом працівників керівники підприємств вимагають від своїх служб, які відповідають за роботу з кадрами (кадрові департаменти, відділи кадрів, HR-служби, служби безпеки, IT-підрозділи і т.п.), забезпечити «прозорість» виробничих процесів, для чого використовуються як відкриті (явні для працюючого), так і приховані методи: прослуховуються і записуються розмови по мобільному і стаціонарному робочих телефонах, перевіряються SMS-повідомлення, вивчається історія сайтів, які відвідує співробітник, проглядається електронна пошта тощо. Комп'ютерні технології дають змогу керівнику або спеціально уповноваженим особам у будь-який момент перевірити екран будь-якого робочого комп'ютера на підприємстві (офісі і т.п.), щоб встановити, чи використовується він 
працівником в особистих або виробничих цілях. Все відвідування інтернету відслідковуються на корпоративному сервері і обробляється системним адміністратором, який підписує документ про нерозголошення такої інформації.

Нині чимало компаній виробляє програмне забезпечення для моніторингу діяльності співробітників, що дає змогу роботодавцям зазирнути буквально в усі сфери зайнятості, дізнатися, що його працівники роблять в інтернеті. Виявлення подібної «нерегламентованої» поведінки, особливо якщо така поведінка є систематичною, може стати підставою для звільнення або суворого попередження співробітника.

Було б помилково стверджувати, що роботодавець не повинен мати прав і змоги стежити за онлайн-діяльністю працівника. Наприклад, якщо роботодавець має підстави вважати, що співробітник використовує інтернет для розкриття комерційної таємниці, він не може не вживати відповідних заходів для підтвердження або зняття таких підозр, і тоді моніторинг буде вважатися ефективним та належним способом для досягнення належної мети.

Комерційна таємниця може бути розголошена з використанням технічних засобів різними способами - за допомогою копіювання, розміщення інформації «для службового користування» в мережі Інтернет, залишення робочого місця з відкритою на комп'ютері інформаційною базою для обмеженого користування [7, с. 110]. Безумовно, подібні випадки з боку співробітників нехтування інтересами компанії (як навмисні дії, так і через необережність) не мають залишатися без уваги та підлягають суворому контролю і реагуванню з боку роботодавців.

У сучасному світі використання інтернету стало настільки повсюдним, що співробітники нерідко використовують його для особистих потреб (перегляду і відправки приватної електронної пошти, передачі файлів, досліджень і т.п.) без будь-якого наміру або бажання нашкодити своїм роботодавцям такими діями. І хоча здається очевидним, що роботодавці не мають платити працівникам за непродуктивну діяльність, із цього не обов'язково випливає, що вони повинні або мають право таємно перехоплювати, збирати або переглядати інформацію на комп'ютерах працівників, особливо якщо це відбувається під час неоплачуваних частин робочого дня.

Якщо звернутися до досвіду США, то ще в 1917 р. окружний суд Північного округу штату Огайо заявив, що кожна людина має право на недоторканість приватного життя в своєму будинку, у своїй оселі та за місцем своєї роботи. Закон про конфіденційність електронного зв'язку 1986 р. (ЕСРА) є єдиним федеральним актом у США, який може застосовуватися до ситуацій моніторингу зайнятості співробітника в інтернеті. ЕСРА приймався для поновлення й уточнення федеральних засобів захисту і стандартів конфіденційності з метою кардинальних змін у галузі нових комп'ютерних і телекомунікаційних технологій [8, p. 853].

За нормами Ради Європи, роботодавці мають запобігати неправомірному і невиправданому втручанню в реалізацію права працівника на недоторканість приватного життя. Цей принцип поширюється на всі технічні пристрої та інформаційно-комунікаційні технології, що використовуються працівником. Зацікавлені особи мають належним чином і $з$ певною періодичністю повідомляти співробітників про застосування прозорої політики конфіденційності. До переліку інформації, що повідомляється співробітникам, про політику конфіденційності, яку проводить компанія, мають входити відомості про цілі збору і обробки, терміни зберігання або копіювання інформації, про трафік і архівування професійних електронних повідомлень. Така інформація має регулярно оновлюватися.

Доступ роботодавця до професійних електронних повідомлень його працівників, які були завчасно повідомлені про таку ймовірність, у разі необхідності, може бути відкритий виключно з метою безпеки або з інших законних підстав. Якщо перевіряється співробітник, відсутній на робочому місці, роботодавець має вжити необхідних заходів і передбачити відповідні процедури, спрямовані на забезпечення доступу до професійних електронних повідомлень тільки в тих випадках, коли це $\epsilon$ нагальною службовою необхідністю. Доступ має здійснюватися щодо відповідного працівника способом, який найменш його турбує і тільки після його повідомлення. Зміст, відправка і отримання особистих електронних повідомлень на робочому місці не підлягають моніторингу за жодних обставин.

Звільняючи працівника з організації, роботодавець має вжити необхідних організаційних і технічних заходів для автоматичного відключення акаунта електронних повідомлень працівника. Якщо для ефективного управління організацією, необхідно відновити зміст акаунта працівника, роботодавець має зробити це до того, як працівник буде звільнений i, за можливості, в його присутності. 
У справі «Копланд проти Сполученого Королівства» Європейський суд із прав людини ухвалив, що Суд не виключає, що контроль за використанням працівником телефону, електронної пошти та інтернету на робочому місці в певних ситуаціях може бути визнаний «необхідним у демократичному суспільстві» для досягнення законної мети [9 ].

В українському трудовому законодавстві механізми захисту права недоторканості приватного життя працівника регламентовані досить неповно, межі вторгнення роботодавця в приватне життя працівника на робочому місці не регламентовані зовсім.

Межі допустимості здійснення роботодавцем контролю і моніторингу дій працівників у робочий час (перевірка електронної пошти, відстеження інтернет-активності, використання офісного обладнання) і загалом поведінки працівників на робочих місцях і поза ними - проблема не тільки українського, а й зарубіжного законодавства. За кордоном працівники досить часто звертаються до суду із позовними заявами про порушення їх приватного життя, конфіденційності листування. Однак якщо роботодавець може довести доцільність таких дій для ефективності ведення свого бізнесу, обмеженість сфери контролю виключно питаннями, безпосередньо пов'язаними $з$ трудовими функціями працівників, і відсутність у цьому особистих мотивів, то в таких випадках суди стають на бік роботодавця $[10$, с. $37-43]$.

Судова і правозастосовна практика при розгляді питання про правомірність використання інтернету на робочому місці встановлює наступне. Факт відвідування працівником сайтів, що не стосуються його роботи, має бути підтверджений і не викликати сумнівів. Крім роздруківки переліку відвіданих інтернет-сторінок, роботодавець має надати суду докази того, що саме цей працівник використовував персональний комп'ютер у відповідні проміжки часу. Найчастіше це можна обгрунтувати наявністю персонального пароля в кожного користувача робочого комп'ютера.

У працівника має бути посадова інструкція, з якою його необхідно ознайомити відповідним чином, оскільки за відсутності встановлених посадових обов'язків неможливо довести, що відвідування інтернету не було з ними пов'язано. Отже, наявність технічної можливості вийти в інтернет із робочого комп'ютера, так само, як і відсутність встановлених обмежень на відвідування тих чи інших ресурсів, ще не свідчить про схвалення роботодавцем використання інтернету на робочому місці.

Як правило, у змісті локальних нормативних актів підприємств прямої заборони на використання інтернету в особистих цілях не потрібно. Суди при цьому виходять із того, що заняття іншою діяльністю, крім виконання прямо покладених на працівника обов'язків, свідчить про порушення ним трудової дисципліни. Разом із тим у трудовий договір, посадову інструкцію або правила внутрішнього трудового розпорядку рекомендується включати пункт, який наказував би працівникові використовувати доступ до інтернету тільки в службових цілях. Відвідування сайтів, що не стосуються роботи співробітника, з метою відпочинку або відволікання від основної роботи (особливо в соціальних мережах) рекомендується розцінювати як порушення трудової дисципліни [11, с. 55-65].

Висновки. Сучасні зміни, що відбуваються в соціально-трудових правовідносинах, вимагають розробки нових структурно цілісних, узгоджених за цілями та методами правових стратегій регулювання суспільних відносин в умовах цифрових технологій. Нині дедалі більше українців віддають перевагу дистанційній та надомній роботі, яка дозволяє гідно заробляти не лише фахівцям певних галузей, а й мало захищеним верствам населення: пенсіонерам, багатодітним жінкам, матерям-одиначкам. Однак, якщо суспільство вже цілком та повністю готове сприймати, втілювати в життя та отримувати реальні результати від такої співпраці, вітчизняне законодавство лише налаштовується на нові відносини. Пріоритетними напрямами законодавчого регулювання трудових відносин $є$ сучасні тенденції та практика поєднання інформаційних технологій i трудових відносин, інструментів IT-нагляду та контролю за дотриманням правил внутрішнього трудового розпорядку, умови забезпечення і можливості віддаленої роботи тощо.

\section{Список використаних джерел:}

1. Galazka, Anna Milena. Report on the global survey into the use of information and communication technologies in national labour administration systems / International Labor Office, Governance and Tripartism Department. Geneva: ILO, 2015. URL: https://www.ilo.org/wcmsp5/ groups/public/ed_dialogue/ed_dialogue_msu/documents/publication/wcms_422057.pdf.

2. Moreira Teresa Coelho. The Digital To Be or Not To Be: Privacy of Employees and the Use of Online Social Networks in the Recruitment Process. GSTF International Journal of Law and Social Sciences (JLSS). 2013. Vol. 2 No. 2, April. 
3. Пашковська Т. ІТ-інструменти у трудових відносинах: можливості є, законів - немає. Юридична газета оn-line. 2016. № 42 (540). URL: https://yur-gazeta.com/publications/events/ itinstrumenti-u-trudovih-vidnosinah-mozhlivosti-e--zakoniv--nemae.html.

4. Конвенція № 177 Міжнародної організації праці «Про надомну працю» від 20.06.2006 p. URL: https://zakon.rada.gov.ua/laws/show/ru/993_327/sp:max25.

5. Конвенція МОП «Про працю в морському судноплавстві» від 23 лютого 2006 р. URL: https://zakon.rada.gov.ua/laws/show/993_519.

6. Закалюжная Н.В. Правовое регулирование нетипичных трудовых отношений. Монография. Москва : КОНТРАКТ, 2013. 60 с.

7. Клочков М.А., Полетаев Ю.М. Материальная ответственность работодателя перед работником: теоретические и практические аспекты : научно-практическое пособие. Москва : Проспект, 2016. $240 \mathrm{c}$.

8. Frayer, Charles E. Employee privacy and Internet monitoring: Balancing workers 'rights and dignity with legitimate management interests. The Business Lawyer; Chicago, 57.2 (Feb 2002): pp. 857874. URL: https://www.researchgate.net/publication/299064030_Employee_Privacy_and_Internet Monitoring_Balancing_Workers'_Rights_and_Dignity_with_Legitimate_Management_Interests.

9. Постанова Европейського суду з прав людини від 3 квітня 2007 р. у справі «Копланд проти Сполученого Королівства» (Copland v. the United Kingdom) (скарга № 62617/00). URL: http://www.nsj.gov.ua/files/1529653122Рішення\%20ССПЛ\%20тест\%20ВККСУ_ОНОВЛЕНЕ_червень_OK_20.06_ост.pdf.

10. Терещенко Л.К. Правовой режим персональных данных и безопасность личности. Закон. 2013. № 6. С. 37-43. URL: http://center-bereg.ru/h159.html.11. Бурцева Н. Использывание Интернета вне связи с трудовой функцией как основание для применения дисциплинарного взыскания. Трудове право. 2014. № 4. С. 55-65.

12. Заяць Т.А. Модернізація соціально-трудових відносин України: пріоритетні напрями та принципи реалізації. Демографія та соиіальна економіка. 2013. № 2 (20). С. 181-182. 